\title{
FHDC1 wt Allele
}

National Cancer Institute

\section{Source}

National Cancer Institute. FHDC1 wt Allele. NCI Thesaurus. Code C114605.

Human FHDC1 wild-type allele is located in the vicinity of $4 \mathrm{q} 31.3$ and is approximately 43 $\mathrm{kb}$ in length. This allele, which encodes $\mathrm{FH} 2$ domain-containing protein 1 , may be involved in cytoskeletal and microtubule dynamics. 